\title{
Teaching Chemistry with Arduino Experiments in a Mixed Virtual-Physical Learning Environment
}

\author{
N. Papadimitropoulos ${ }^{1}$ (D) $\cdot$ K. Dalacosta ${ }^{1}$ (D) E. A. Pavlatou ${ }^{1}$ (D)
}

Accepted: 29 December 2020 / Published online: 29 January 2021

(c) The Author(s), under exclusive licence to Springer Nature B.V. part of Springer Nature 2021

\begin{abstract}
A study with K-9 Greek students was conducted in order to evaluate how the declarative knowledge acquisition was affected by incorporating Arduino experiments in secondary Chemistry Education. A Digital Application (DA) that blends the use of the Arduino sensors' experiments with digital educational material, including Virtual Labs (VLs), was constructed from scratch to be used through the Interactive Board (IB) as a learning tool by three different student groups $(N=154)$. In the first stage of the learning process, all groups used only the digital material of the DA. In the second stage, the three groups used different learning tools of the DA. Through the IB, the first group used Arduino experiments, the second one the VLs, and the third only static visualizations. A pre- to post-test statistical analysis demonstrated that the first two groups were equivalent in regard to achievement in declarative knowledge tests and of a higher level than the third group. Therefore, it can be concluded that conducting Arduino experiments in a mixed virtual-physical environment results in equivalent learning gains in declarative knowledge as those attained by using VL experimentation through the IB.
\end{abstract}

Keywords Arduino $\cdot$ Virtual lab $\cdot$ Interactive board $\cdot$ Secondary education $\cdot$ Chemistry

\section{Introduction}

The incorporation of Information and Communications Technologies (ICT) in secondary education appears to be an important factor in European countries' strategy, since it seems to ensure the effectiveness of their education systems (Conrads et al., 2017) and the competitiveness of their economy (European Commission, 2018). New ICT tools are constantly being developed, based on which various learning environments can be designed. However, gauging student achievement is important not only for the development of sound pedagogical best practices but also for school financial administration as an investment on new ICT tools should be justified properly.

A state-of-the-art learning tool is the microcontroller technology, with Arduino being one of the most popular, as it is suitable for people with little knowledge of electronics

E. A. Pavlatou

pavlatou@chemeng.ntua.gr

1 Laboratory of General Chemistry, School of Chemical Engineering, National Technical University of Athens, 9, Heroon Polytechniou Str., Zografos Campus, GR-15780 Athens, Greece
(Urban, 2014). It can be used in conjunction with various low-cost sensors to produce highly accurate and reliable measurements (Alo et al., 2020; Pino et al., 2019). Therefore, it is considered a valuable tool for implementing laboratory work in Chemistry education (Kubínová \& Šlégr, 2015; Grinias et al., 2016). Through the addition of Arduino to the infrastructure of schools, teachers are given the opportunity to use it as a means of experimentation as a support of common teaching practices. For example, in Greek Chemistry Secondary Education, some common practices involve teaching without experiments or with experiments through demonstration (Tountoulidis, 2011), or even using Virtual Labs (VLs), videos, etc., on the Interactive Board (IB) (Vagelatos \& Angelopoulos, 2017).

If the empirical data can support that the addition of Arduino experiments can offer at least equivalent learning outcomes as current practices, given their many other affordances, an argument can be made for their acceptance as a support of current practices (Brinson, 2015). So, this study aims to evaluate the learning outcomes on Chemistry knowledge acquisition of K-9 students by substituting VL experiments through demonstration with Arduino ones in a mixed virtual-physical learning environment. 


\section{Theoretical Framework}

\section{RLabs and VLabs}

Experimentation can develop understanding related to the scientific content, problem solving skills, science processes skills, understanding the nature of science, students' selfconfidence and high-order cognitive skills (Ural, 2016; Wahyuni \& Analita, 2017; Tsaparlis \& Gorezi, 2005).

However, in Greek Junior High schools, teaching Chemistry is mainly based on factual knowledge with limited mathematical foundations, according to the instructions of the Greek national curriculum. In addition, although hands-on laboratory work is an indispensable element of understanding chemistry courses, various limiting factors such as insufficient lab infrastructure, overpopulated classes, lack of teachers' self-confidence, and an excessive amount of time and effort required to conduct accurate experiments result to the use of experiments through demonstration and in many cases in the absence of experiments (Davenport, 2018; Tatli \& Ayas, 2013; Kurbanoglu \& Akim, 2010; Tountoulidis, 2011).

Consequently, Chemistry teachers usually focus on the presentation of school textbook theory on the conventional board using static visualizations of the school textbook. Students are required to acquire mainly declarative knowledge of Chemistry and applied exams focus on testing the acquisition of this type of knowledge. The declarative knowledge is domain-specific, consisting of facts, theory, names, relations, and links representing meaningful connections between concepts, whereas procedural knowledge includes the effective implementation of skills and strategies (Hong, 2018; Stevenson, 1998; Sariscsany \& Pettigrew 1997; Anderson, 1983). The main learning process of declarative knowledge is understanding and remembering the knowledge, whereas procedural knowledge is firstly knowing it is associated declarative knowledge, and then of enacting the skill via practice (Hong 2018).

Furthermore, the activities using VLs, videos, etc., on the IB that Greek teachers may apply can foster declarative knowledge acquisition (Hong, 2018; Webster, 2016; Sariscsany \& Pettigrew, 1997). VLs are educational environments that are considered as alternatives of RLs (Wu et al., 2019; Zacharia \& Anderson, 2003; Dalgarno et al., 2009). In them virtual objects like Chemistry, instruments and substances can be manipulated by students during the learning process. Researchers highlight the educational use of VLs for their contribution to learning (Zacharia et al., 2019; Olympiou \& Zacharia, 2012; Zacharia \& Olympiou, 2011; Zacharia \& Anderson,
2003; Zacharia, 2007) and suggest that they may have complementary affordances with physical hands-on manipulatives (Kapici et al., 2019).

However, some educators are critical in exposing students only to VLs, as the only way to acquire fine laboratory skills is through actual hands-on experience (Potkonjak et al., 2016) and state that careful consideration should be given concerning the question if a VL would be the best teaching tool (Crandall et al., 2015). Physical hands-on experiments engage students (Flick, 1993) and offer realistic contexts that provide perceptually rich sensory-motor experiences, allowing students to connect new to prior experiences (GoldStone \& Son, 2005). In addition, some researchers found that the use of ICT may have relatively small effects on academic outcomes (Cristia et al., 2017; Ma et al. 2020). This can be attributed to the fact that effects on knowledge acquisition depend on the manner teachers integrate ICT into their teaching process (Comi et al., 2017) and to the fact that negative effects could occur if they are exploited to practice skills and procedures (Falck et al., 2018). As a result, some scholars claim that the use of ICT and especially of virtual representations instead of physical manipulation, deprive students of hands-on experiences leading to negative effects on learning (Scheckler, 2003; Clark, 1994). Instead, they highlight the importance of learning through RL activities (Falck et al., 2018; Wang \& Tseng, 2018; Zacharia et al., 2008; Zendler \& Greiner, 2020). Therefore, the use of VLs is regarded by a large portion of science educators as a surrogate for RLs (Zacharia, 2007).

While research shows that physical and virtual representations have complementary advantages (Olympiou \& Zacharia, 2012), whether or not a physical, virtual, or blended mode is most effective, it likely depends not only on the mode itself but also on the learning content and on the specific design of a representation (Rau, 2020). Selecting physical manipulatives over virtual ones, and vice versa, requires knowing which conditions favor one over the other and the only way to specify this is through further research (Zacharia et al., 2019). Since, we are far from being able to predict when and why a physical or a virtual mode is effective (Rau, 2020), it is interesting to develop and evaluate the learning effects of a mixed learning environment where virtual and physical manipulatives using Arduino microcontroller can be combined.

\section{Microcontroller Technology}

Open-source microelectronics have become increasingly useful in Chemistry due to their low cost (Urban, 2015). A microcontroller is a compact, integrated circuit designed to control specific processes, receive signals from a wide variety of sensors and interact with activators (Enciso et al., 2018). Microcontroller technology has been used in many studies to create an interface of the physical environment with a 
virtual one (Edwards et al., 2019; Kuan et al., 2016; Suwondo \& Sulisworo, 2017; Fatani et al., 2018; Papadopoulos \& Jannakoudakis, 2016; Spikol et al., 2018). Measurements taken in physical systems using Arduino sensors can be transmitted through a USB cable or wirelessly (Mavridis \& Tsiatsos, 2017), e.g. through an HC-06 Bluetooth module, to a PC, a smartphone or a tablet. The acquired data can be processed in digital form by using appropriate software (El Hammoumi et al., 2018; Nichols, 2017; Grinias et al., 2016) and displayed directly on a screen in real-time (Urban, 2014).

Arduino and other similar microcontrollers have already been used in various educational Chemistry applications as there is a wide variety of sensors which can be used, that are not expensive and produce highly accurate and reliable measurements (Pino et al., 2019). Arduino technology has been exploited for the construction of inexpensive Chemistry measuring devices such as $\mathrm{pH}$ meters and thermometers (Kubínová \& Šlégr, 2015) that can even be used for students with visual impairment (Costa \& Fernandes, 2019; Soong et al., 2018). Teachers can use these devices, exploiting a projector, an IB (Walkowiak \& Nehring, 2016), or an LCD display (Petô, 2020) in order to monitor measurements.

For example, Kubínová and Šlégr (2015) proposed an inexpensive instrument based on Arduino technology as an educational tool for $\mathrm{pH}$ and temperature measurements in secondary education. This experimental device can be used in combination with a large enough display to be easily readable from every point in the classroom during demonstrations and experiments performed by students.

Arduino Integrated Development Environment (IDE) is the most commonly used environment for programming and for displaying data through a USB connection with a PC (Urban, 2014). In addition, researchers developed open-source software written in Python to enable easy, inexpensive data acquisition from Arduino, compatible with PC or Mac (Grinias et al., 2016).

These technological capabilities point out that Arduino is appropriate for integrating the ability to produce measurements with physical instruments and substances in a mixed virtualphysical learning environment. This learning environment should have the adaptability to be used either for demonstrations or experiments performed by students, for which Arduino technology has been proven as appropriate (Kubínová \& Šlégr, 2015). In addition, in Greece, the large screens that are available for demonstration in most schools are IBs, and therefore, a mixed virtual-physical learning environment should have the ability to interface with these tools.

\section{Aims of the Study}

Arduino sensors can be used in order to perform experiments through a demonstration using physical instruments and substances, and the acquired data can be processed and displayed on the IB. In addition, the IB can be exploited in order to apply activities through VLs. With proper design, a mixed virtual-physical learning environment could be achieved by incorporating Arduino instrumentation through IB.

Therefore, based on the above learning materials, instruments and techniques, three research questions have been set:

1. By using IB, is there a difference in declarative knowledge acquisition when teaching with a mixed virtual-physical environment vs. teaching with VL?

2. By using IB, is there a difference in declarative knowledge acquisition when teaching with a mixed virtual-physical environment vs. teaching with no experiments at all?

3. By using IB, is there a difference in declarative knowledge acquisition when teaching with VLs vs. teaching with no experiments at all?

In order to answer these questions, a Digital Application (DA) was constructed which incorporated text, images, videos, digital concept maps, and VLs, aimed to be used through the IB. Also, an interface was added by which an Arduino sensor could be controlled, calibrated, and monitored through the IB.

\section{Research Design and Tools}

\section{Construction of the DA}

A DA was constructed from scratch that concerned the thematic unit of "acids and bases." This unit corresponds to the 3rd class of Greek Junior High School, where K-9 students are attending. Course objectives were defined after a thorough analysis of the school textbook, by taking into consideration the instructions given by the Greek Educational Policy Institute and common student misconceptions reported in the literature (Demircioglu et al., 2005; Horton, 2007). The objectives were evaluated by 15 in service Chemistry teachers, 4 school counselors, and 1 academic Chemistry teacher. Then, manuscripts of concept maps involving the content to be taught were constructed and discussed with 6 school teachers.

Twelve simulations of VLs were constructed from scratch (Fig. 1). All the VLs, supplemented by additional digital objects, like digital concept maps, animations, and photos, were utilized for the production of the DA (Fig. 2). Mayer and Moreno (2002) rules were taken into consideration, in order to construct all the necessary digital material and efforts were made to refer to real-life situations (e.g. wasp bites, stomach disturbances, everyday materials) so that the new knowledge would be meaningful to students (Herranen et al., 2019; Childs et al., 2015; Broman et al., 2018; Bulte et al., 2006). 
Fig. 1 An indicative screen of one VL

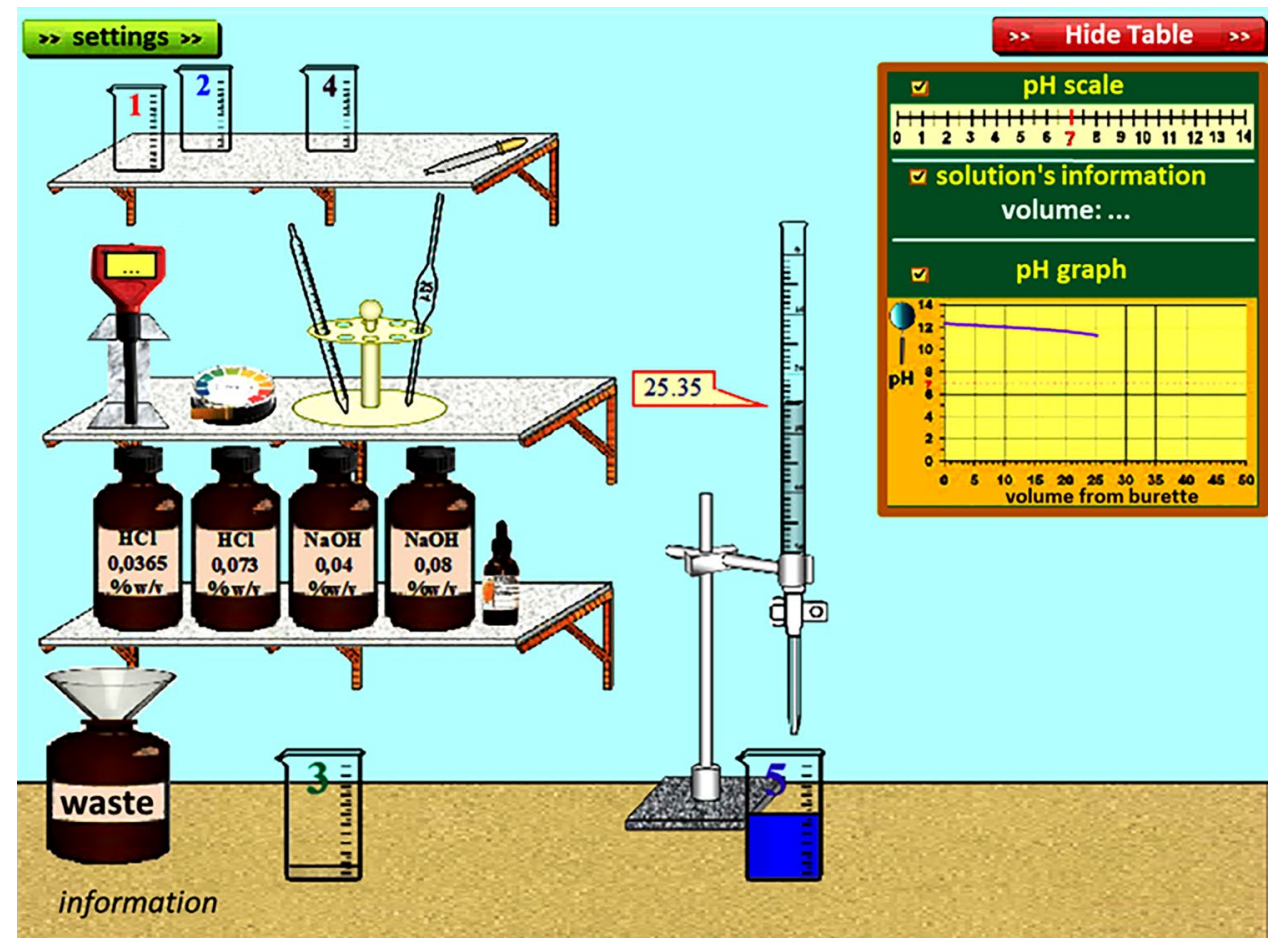

The developed DA had a predetermined learning path that was divided into continuous subsections. Each of these subsections had three steps according to the Predict-ObserveExplain (POE) model (Zacharia et al., 2008). For example, in
"Research Design and Tools" there were VL activities in which the first step was to predict the effect of adding another solution on the $\mathrm{pH}$ or on the color of the solution. In the next step, the teacher performed this procedure using the appropriate virtual
Fig. 2 One of the VLs embedded within the DA

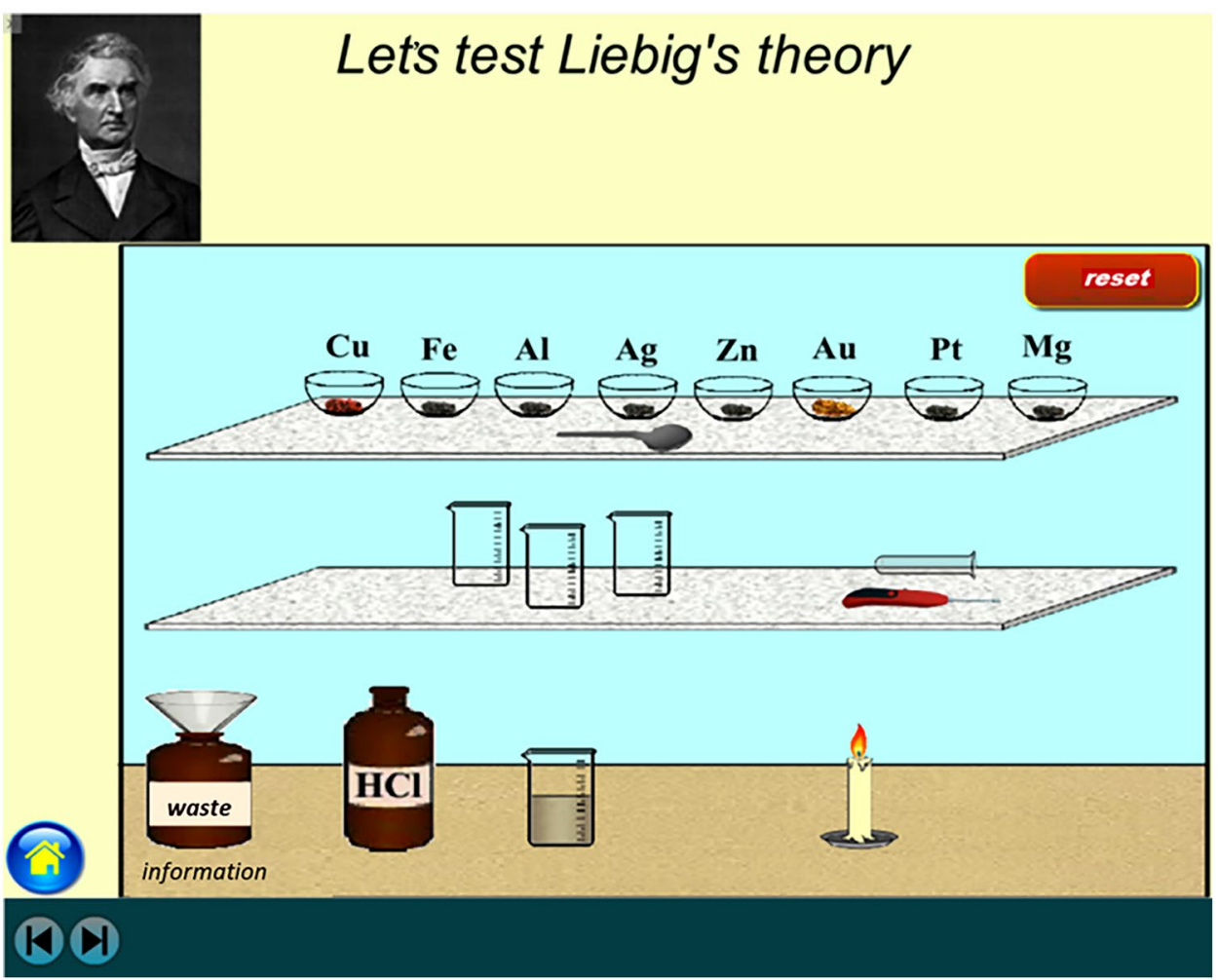


instruments and substances while students observed the result in a plenary format. At the last step, students consulted in groups of two in order to reach a conclusion, to rationalize potential differences between the prediction and the result, and to derive a general rule without the use of mathematical formalism, as this is not part of the curriculum. These steps were followed during the construction of the DA given that many Greek Science teachers were familiar with them due to their attendance to advanced level learning of educators in ICT performed in recent years (Nikolopoulou \& Gialamas, 2016).

A table of contents and a detailed menu were incorporated to be used for accessing any subsection of the DA (Fig. 3).

According to De Jong (2019), adaptive forms of guidance should be available in educational technology. Therefore, a menu was added in some VLs in order to give to the "experienced" user the flexibility to select which instruments will be used for a specific task, in order to follow a different path than the predefined one (Fig. 4).

The construction of the DA followed all the aforementioned stages as shown schematically in Fig. 5.

\section{Arduino Interface}

An Arduino pH Sensor had to be connected and manipulated through the DA on the IB. In order to accomplish this, an Arduino Uno R3 microcontroller and a Gravity Analog pH sensor v1.1 were utilized (DFRobot, 2019). Connection of the microcontroller with the $\mathrm{PC}$ was made possible through a USB cable and as alternative through a HC-06 Bluetooth module (Table 1).

In order to connect both the $\mathrm{pH}$ sensor and the Bluetooth HC-06 module on the microcontroller, the use of a breadboard

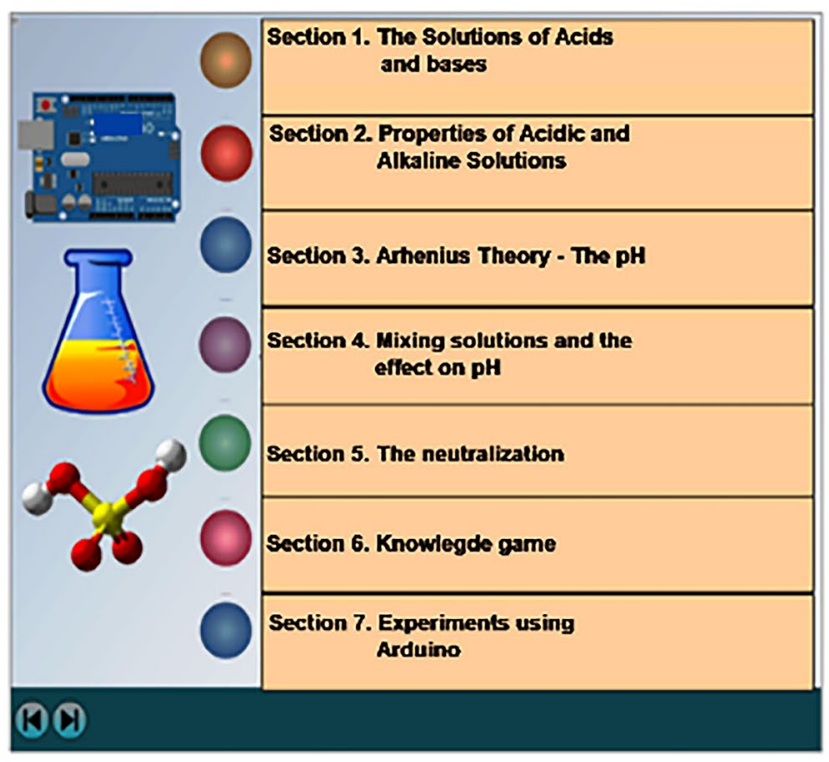

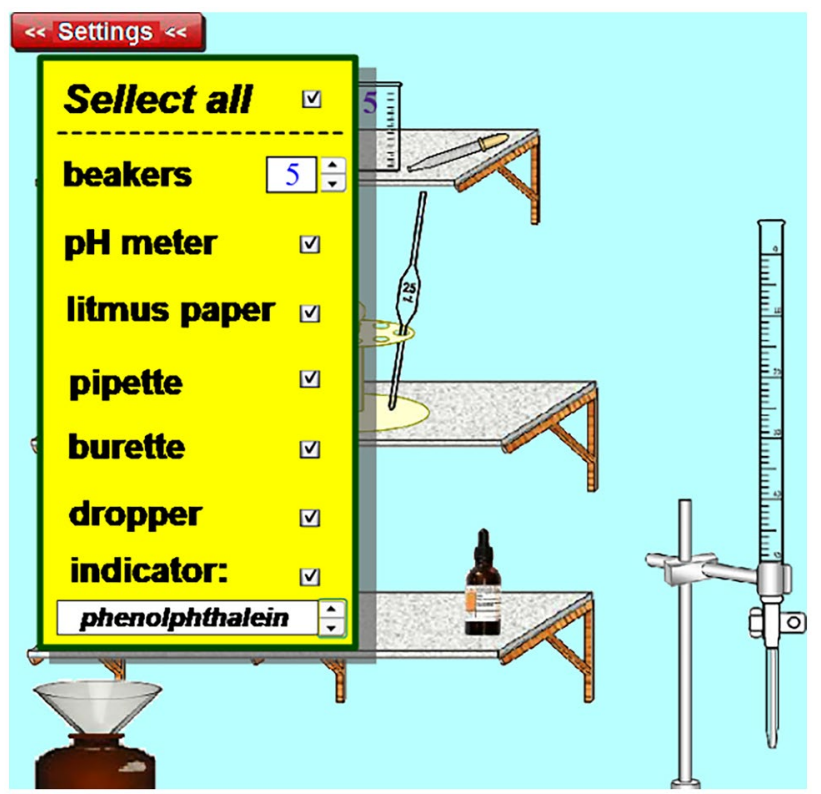

Fig. 4 The instrument selection menu

was required. By providing both types of connection (i.e. wired and wireless), the educator can use either in accordance with the layout of the classroom or School Lab and the available infrastructure. The Arduino microcontroller, the breadboard, the Bluetooth module, the $\mathrm{pH}$ sensor, and the battery were placed in a small case, from which the USB cable and the sensor electrode came out (Fig. 6). In this way, the Arduino system is relatively portable between different IBs.

Arduino was programmed using Arduino IDE on a Windows PC. The sketch developed for that purpose
TABLE OF CONTENTS

is 5 ith

CONTENTS

Unit 1

Title

Introduction

Ideas about acids and bases

Introduction to indicators

What is an indicator?

The red cabbage (VLab)

Laboratory Solutions (VLab)

Safety precautions - Hazards

Conclutions

Concept map about acld - bases

Unit 2

Title

Ideas about solution properties

\section{(1)(1)}

Fig. 3 Table of contents (left) and detailed submenu (right) of the DA 
Fig. 5 Stages followed for the design of the DA

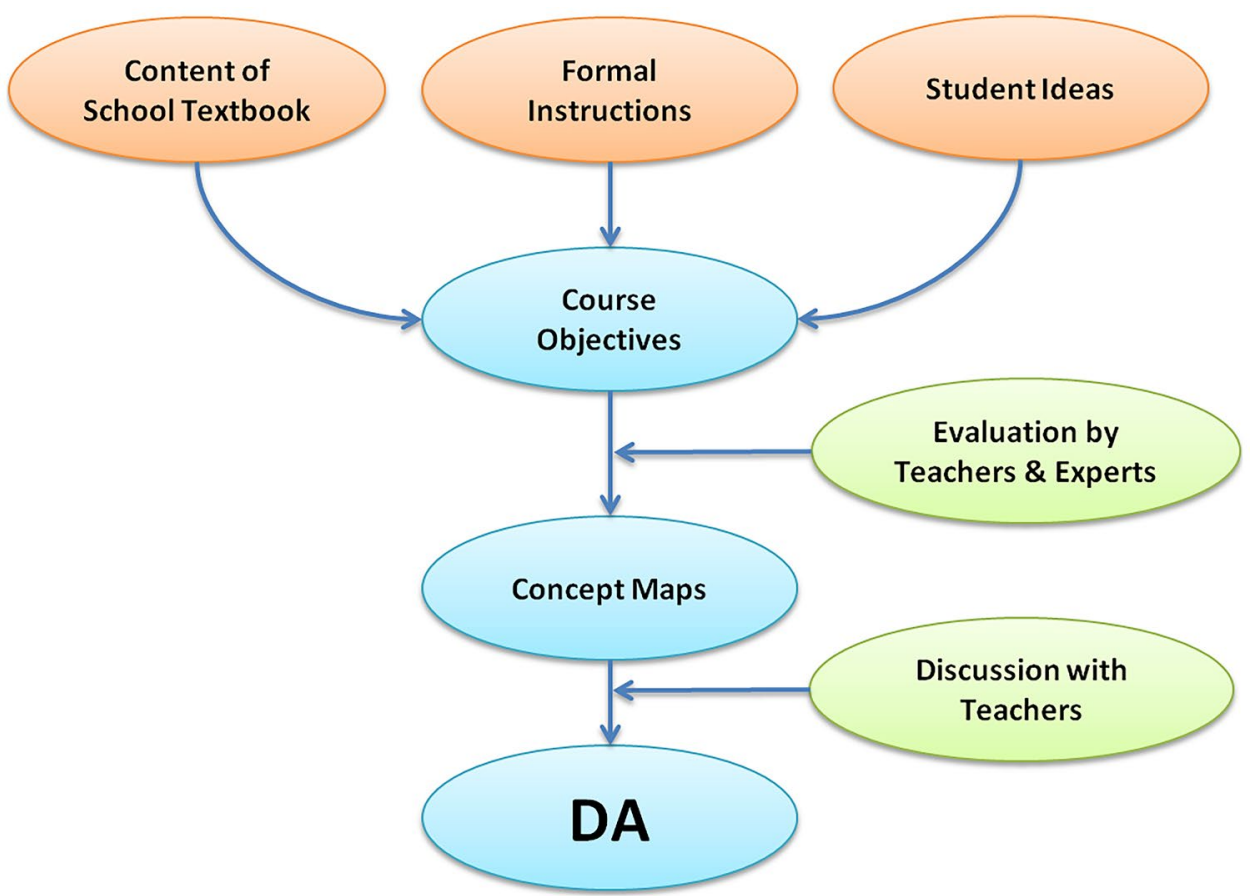

Table 1 Connections on the microcontroller

\begin{tabular}{lll}
\hline & $\begin{array}{l}\text { Sensor/ } \\
\text { Module } \\
\text { port }\end{array}$ & $\begin{array}{l}\text { Micro- } \\
\text { controller } \\
\text { port }\end{array}$ \\
\hline pH & Signal & A0 \\
& VCC & $5 \mathrm{~V}$ \\
& GND & GND \\
HC-06 & RXD & TXD \\
& TXD & RXD \\
& VCC & $5 \mathrm{~V}$ \\
& GND & GND \\
\hline
\end{tabular}

relied mainly on the code provided by the sensor's manufacturer (DFRobot, 2019) and on the Uduino library (Teyssier, 2019). This sketch permitted Arduino to calculate the $\mathrm{pH}$ value from the electrode output voltage, and the resulting value was transferred in real-time through USB or Bluetooth connection into a
Windows PC by using Uduino library and a C\# code that exploited the Uduino plugin (Teyssier, 2019) and was developed on Unity 3D Visual Studio. By using the code, $\mathrm{pH}$ values were displayed on a virtual analog/digital $\mathrm{pH}$ meter (Fig. 7). "Calibration" of the virtual pH meter was realized before experiment using distilled water as a standard solution by pressing an "up" or "down" button on the digital $\mathrm{pH}$ meter.

In addition, calibration of the sensor was realized by the teacher before conducting the Teaching Intervention (TI) using $\mathrm{pH}=4.00$ and $\mathrm{pH}=7.00$ standard solutions (DFRobot, 2019). All of these components were incorporated in the start screen of the DA (Fig. 7).

\section{Paper-and-Pencil Worksheets}

Two worksheets were constructed to be used in combination with the DA. In these worksheets guidance of student's attention to the important aspects of the learning task
Fig. 6 The Arduino system was placed inside a small case which is represented by the dashed line and was either wired or wirelessly connected to the IB through a PC

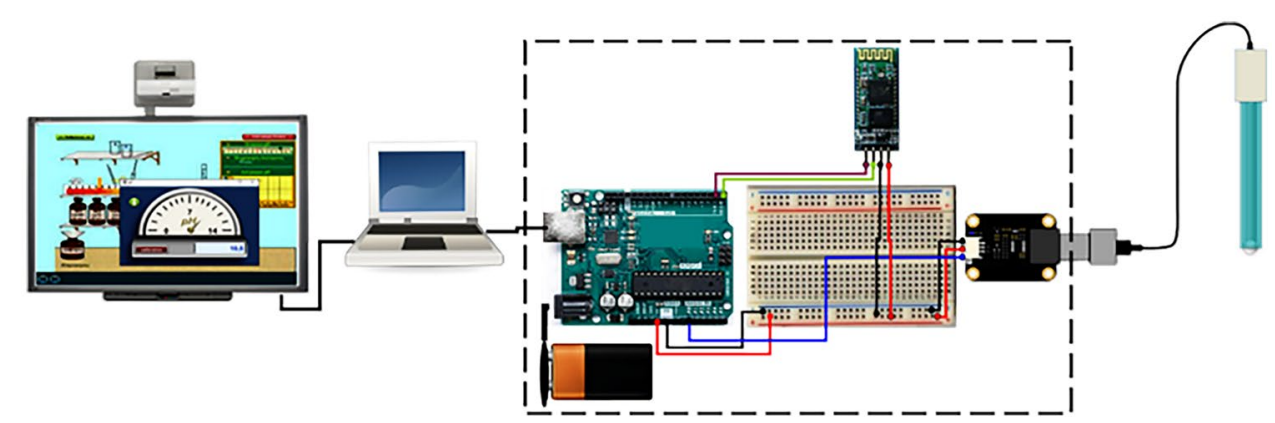


Fig. 7 The start screen of the DA includes virtual objects like VLs, video, digital concept maps and theory text, the virtual $\mathrm{pH}$ meter analog/digital screen as an interface with the Arduino sensor, and the instructions/ setup menu

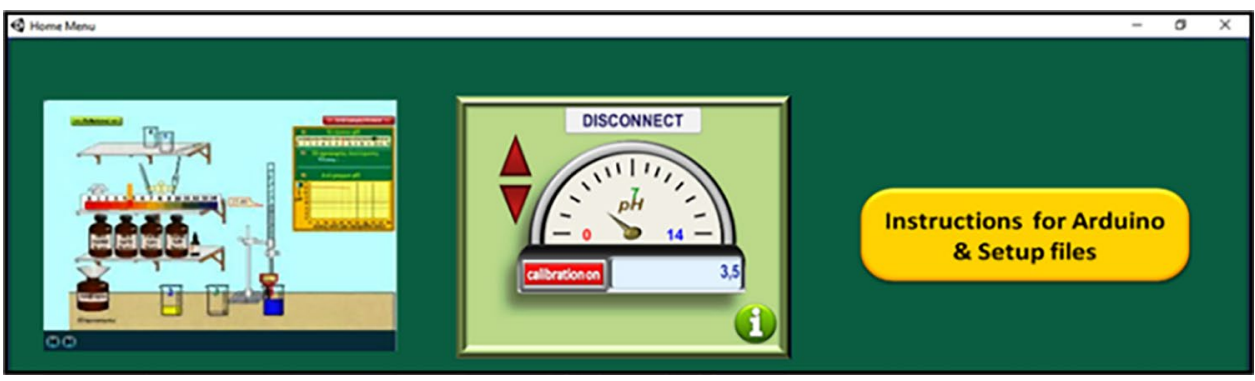

was achieved by breaking tasks to smaller, simpler, more manageable (sub)tasks (Efstathiou et al., 2018; De Jong, 2019).

More specifically, the first worksheet (WS1) was constructed in such a way to follow the above-mentioned steps of activities according to the POE model. This worksheet corresponded to the first three sections of the DA concerning: (a) an introduction to household and laboratory acidic and alkaline solutions, (b) the properties of the acidic and alkaline solutions, and (c) Arrhenius theory and $\mathrm{pH}$ measurement methods.

The second worksheet (WS2) followed a different path than the predetermined of the DA regarding mixing of solutions and their effect on the $\mathrm{pH}$ value, and the neutralization of solutions. This worksheet followed inquiry learning phases with a number of relevant sub processes (Pedaste et al., 2015) that could help teachers and students to monitor the learning process (De Jong, 2019). This type of learning was selected, since it is a part of science curricula worldwide (Herranen, 2019) and results of this research could be comparable between various educational systems. Additionally, research data have shown that the combination of POE and inquiry was very successful in providing meaningful experience through experimentation with physical manipulation and/or virtual manipulation (Zacharia et al., 2008), and therefore, it was exploited in this research. However, experiments through demonstration were performed in the research given that this is the most common Greek teaching practice of experimentation.

Three versions of the WS2 were constructed and differentiated only in the Experimentation sub-phase of the followed inquiry-based framework. Firstly, during Orientation phase, all students were introduced to the problem to be studied concerning the changeable $\mathrm{pH}$ value of Greek sea water (Gianni et al., 2013) as well as, of acid-rain due to human activities or natural phenomena. Following the conceptualization phase, students were asked to hypothesize the potential effects of different $\mathrm{pH}$ values on aquatic life, on metal constructions, and on ancient marble monuments. In the next step, students proposed under appropriate assistance supplied by the teacher which laboratory experiments had to be carried out in order to determine the $\mathrm{pH}$ value changes as a result of the above human activities or natural phenomena.
Afterwards, during Experimentation, the three versions of WS2s were differentiated in regard to the means by which students studied possible $\mathrm{pH}$ changes. According to the first version of WS2, students had to observe experiments implemented by the teacher through Arduino sensors, using solutions like tap water, vinegar and glass cleaner as well as simple instruments such as beakers, volumetric cylinders and wash bottles. A virtual analog/digital $\mathrm{pH}$ meter screen was used through the IB in order to record the $\mathrm{pH}$ changes during the experiments. In the second version of the WS2, students had to observe the corresponding VL experiments of the DA on the IB. In the third version, only drawings of glassware and solutions on the IB were presented and the outcomes of the corresponding experiments were provided to the students without performing them.

At the end of each experiment, students were divided in groups of three or four in order to draw conclusions deduced from the experiments and then to make a hypothesis on the possible effects of the resulted $\mathrm{pH}$ value on aquatic life species, metal constructions, and on ancient monuments based on literature data (Gianni et al., 2013; Baedecker \& Reddy, 1993; Charola, 1987; Kumar, 2017; Camuffo, 1992).

In the whole learning process, the educator had control over the IB and coordinated students' activities, ensuring that they all kept the same pace of learning and the students observed Arduino or VL experiments in a plenary format.

\section{Participants}

In order to answer research questions, a pre- to post-test comparison was carried out in two public Junior High schools in Athens Greece during the school year 2018-2019. Two school teachers and 154 students participated in the main research. Consent was received from the School principal and the Parents Board of each School. The teachers were in service and had attended an official training program, named B-level, regarding the use of ICT in education (Nikolopoulou \& Gialamas 2016). Students were 14 to 15 years old and attended the 3rd grade of Junior High school. Students in each school were distributed in three classes, in alphabetical order, and each student participated only in one type of group. The first group was named Arduino (AR) Group, the second 
Virtual Lab (VL) Group, and the third one corresponds to the Control (C) Group.

Weekly consultations by the researchers were performed with the two teachers of the six classes participating in the study, in order to follow similar teaching interventions. It should be noticed that both teachers used the same DA, worksheets and questionnaires as well as, all groups had been taught the same didactic units according to the curriculum before conducting the research.

\section{Instruments}

In this study, the acquisition of declarative knowledge was evaluated in order to test the impact of the DA in a context of common Greek teaching practices. For this type of knowledge, objective-type questionnaires, like multiple choice, are considered as appropriate in the scientific literature (Ackerman \& Smith, 1988; Abu-Zaid \& Khan, 2013; Chéron et al., 2016; Dickson-Spillmann et al., 2011; Hong et al., 2018; Palmer \& Devitt, 2007; Sariscsany \& Pettigrew, 1997; Itzek-Greulich et al., 2015, 2017; Glasson, 1989).

At first, a questionnaire consisting of 40 multiple choice questions was constructed based on the learning goals and common student misconceptions (Cartrette \& Mayo, 2011; Demircioglu et al., 2005; Horton, 2007). Each question had four possible answers and one of which was correct.

Validity and reliability tests of the questionnaire (Q) were carried out (Muijs, 2010; Considine et al., 2005; Escudero et al., 2000). Questions were evaluated in relation to Content and Face Validity by 15 in service Chemistry teachers, 4 school counselors, 1 academic Chemistry teacher, and 20 junior high school students. Following their suggestions, the questions were revised properly. Then the revised questionnaire was administered to 194 students who had just been taught the thematic unit "acids and bases" in order to evaluate the discrimination index (DS) of each question. These students were different from those participating in the main research. DS was calculated from "item to total correlation" and DF from the number of correct answers divided by the number of total answers, by using SPSS software. Only questions that had DS $>0.3$ were retained (Ding \& Beichner, 2009; Escudero et al., 2000). Twenty-five of them were used to construct Q1 (see Appendix) and 14 of them to construct Q2 (see Appendix) according to the learning objectives taught in the particular research phases which are described in Fig. 8. All scores were redacted to a 100-degree scale.

\section{Data Analysis}

\section{Procedure and Data Collection}

Firstly, Q1 (Q1 pre) was distributed to all students as pre-test in order to evaluate if all teams were "equal" in terms of prior declarative knowledge as described in Fig. 8. Afterwards, the first phase of the teaching intervention (TI1) was applied in all groups by using the WS1 as well as, the DA on the IB. At this stage, only experiments with the VLs of the DA were performed. The TI1 concerned basic concepts of the thematic unit, i.e., the categorization of substances into acids and bases, their properties, Arrhenius theory, and pH scale. Then, Q2 was given to all students in order to evaluate if all groups remain "equal" in terms of declarative knowledge of these concepts (see Fig. 8).

In the second phase of the teaching intervention (TI2), the three different versions of the WS2 were used by the AR,
Fig. 8 A schematic representation of the research process including both phases of the applied teaching intervention (TI) and the three assessment Stages. Q1 and Q2 are used questionnaires. WS1 and WS2 are worksheets used during the teaching intervention. In first phase of TI (TI1), all students were taught virtual experiments by using the DA. In the second phase, the TI2 was performed at $\mathrm{AR}, \mathrm{VL}$, and C students' groups exploiting Arduino, Virtual Labs, and static visualizations as a teaching tool, respectively

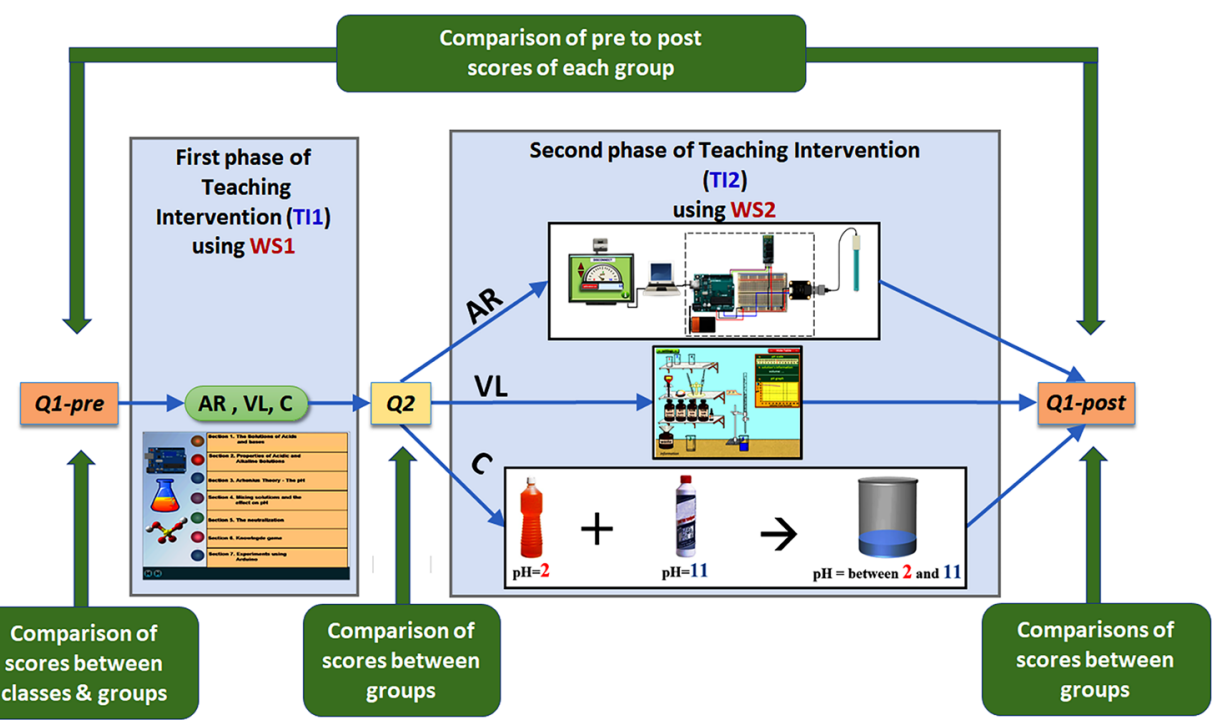


VL, and C groups, respectively. The TI2 concerned changes in $\mathrm{pH}$ when mixing solutions or separating a solution in two parts, dilution and neutralization of solutions. In the AR group experiments by demonstration through the IB were performed using the Arduino. In the VL group only experiments using the VLs of the DA were performed through the IB. In C group no experiments were performed and only graphics of instruments and substances were presented through the IB. Finally, Q1 (Q1post) was redistributed to all students as post-test in order to evaluate declarative knowledge acquisition due to the overall teaching intervention implemented in the research (Fig. 8).

The duration of each assessment was one teaching hour (45 min). The duration of the TI1 was four teaching hours and of TI 2 was $3 \mathrm{~h}$. As Chemistry is taught only one teaching hour per week in Greek junior high schools, all the research procedures lasted for 10 weeks.

\section{Questionnaire Evaluation}

Q1 and Q2 were evaluated by calculating Cronbach's alpha (a) and discrimination (DS)-difficulty (DF) analysis, by using students' answers after each TI implemented in the main experimental procedure (Table 2). In both questionnaires, DSs and DFs and Cronbach's alpha values can be regarded as acceptable (Ding \& Beichner, 2009; Considine, 2005; Escudero et al., 2000).

\section{Groups' Achievement Comparison}

Shapiro-Wilk normality tests on the groups' achievement on Q1 and Q2 were conducted for every assessment stage (Table 3). It was concluded that groups' scores did not follow a normal distribution in most cases.

Therefore, non-parametric statistical tests were applied for group comparisons (Table 4). Kruskal-Wallis test is applied since it is a non-parametric test used to investigate statistical differences where there are more than two independent groups to compare (Roni et al., 2020; MacFarland \& Yates, 2016). In our study, this test was used to evaluate if there are statistically significant differences for comparisons between the three groups. In cases that Kruskal-Wallis test showed a significant difference, pair-wise comparisons with Bonferroni correction (adj sig) and Mann-Whitney test were conducted as post-hoc analysis to determine which group(s) differ (Roni et al., 2020). Moreover, in order to evaluate if there are significant differences before and after teaching intervention, Wilcoxon signed ranks tests were applied for every group (Grzegorzewski \& Śpiewak, 2019). Effect size ( $r=\mathrm{Z} / \mathrm{N} 1 / 2)$ was calculated for which a significant difference was revealed (Tomczak \& Tomczak 2014; Fritz et al., 2011).

The six classes and the three groups (AR, VL, and C) had no significant differences in test scores among them before as well as after the common TI. After the sequence of different TIs, all three groups exhibit significantly higher scores than before with large effect sizes, indicating that all intervention variants had positive effects on learning. Nevertheless, although AR and VL groups exhibited no significant differences to each other, they exhibited significantly higher scores than $\mathrm{C}$ group with medium effect sizes.

\section{Conclusions}

In this study, the effects of conducting Arduino experiments in a mixed virtual-physical learning environment on declarative knowledge acquisition were examined as the Greek curriculum and common teaching practices are focused on this type of knowledge. According to the results, the use of Arduino experiments by the demonstration on the IB instead of VLs through the IB had the same positive effect on students' achievement. Furthermore, both experimentation approaches result in greater learning gains regarding this type of knowledge than the absence of experimentation. Students of $\mathrm{C}$ group who did not observe any manipulation had learning gains that can be attributed only to the appropriate activities accompanied by static

Table 3 Student score medians (MD) and Shapiro-Wilk normality test results

\begin{tabular}{lllll}
\hline Group & Questionnaire & $\mathrm{N}$ & $\mathrm{MD}$ & Shapiro-Wilk \\
\hline ARG & Q1-pre & 50 & 22.00 & $p=0.008$ \\
VLG & Q1-pre & 52 & 24.00 & $p=0.001$ \\
CG & Q1-pre & 52 & 24.00 & $p=0.0219^{*}$ \\
ARG & Q2 & 50 & 85.71 & $p<0.001$ \\
VLG & Q2 & 52 & 75.00 & $p<0.001$ \\
CG & Q2 & 52 & 71.43 & $p=0.024$ \\
ARG & Q1-post & 50 & 82.00 & $p<0.001$ \\
VLG & Q1 post & 52 & 76.00 & $p=0.001$ \\
CG & Q1 post & 52 & 54.00 & $p=0.022$ \\
\hline
\end{tabular}

*Normal distribution
Table 2 Cronbach's alpha and discrimination-difficulty analysis of Q1-post and Q2

\begin{tabular}{lllllllll}
\hline Quest & Number & $a$ & $\mathrm{DS}_{\min }$ & $\mathrm{DS}_{\max }$ & $\mathrm{DS}$ Shapiro-Wilk & $\mathrm{DF}_{\min }$ & $\mathrm{DF}_{\max }$ & DF Shapiro-Wilk \\
\hline Q1-post & 154 & 0.877 & 0.315 & 0.589 & $p=0.357^{*}$ & 0.604 & 0.799 & $p=0.717^{*}$ \\
Q2 & 154 & 0.776 & 0.318 & 0.548 & $p=0.119^{*}$ & 0.490 & 0.877 & $p=0.763^{*}$ \\
\hline
\end{tabular}

*Normal distribution 
Table 4 Comparisons of student scores

\begin{tabular}{llll}
\hline Examined group(s) & Questionnaire(s) & Statistical test & Results \\
\hline 6 Classes vs. each other & Q1-pre & Kruskal Wallis & $p=0.703, \chi^{2}(5)=2.981$ \\
AR vs. VL vs. C & Q1-pre & Kruskal Wallis & $p=0.746, \chi^{2}(2)=0.585$ \\
AR vs. VL vs. C & Q2 & Kruskal Wallis & $p=0.169, \chi^{2}(2)=3.552$ \\
AR vs. VL vs. C & Q1-post & Kruskal Wallis & $p=0.009^{*}, \chi^{2}(2)=9.411$ \\
& & & Bonferroni correction: \\
& & & C vs. VL adj sig $=0.028^{*}$ \\
& & & C vs. AR adj sig $=0.021^{*}$ \\
AR vs. VL & & VL vs. AR adj sig $=1.000$ \\
AR vs. C & Q1-post & Mann-Whitney & $p=0.817, Z=-0.232$ \\
VL vs. C & Q1-post & Mann-Whitney & $p=0.010^{*}, Z=-2.592, r=0.257$ \\
AR & Q1-post & Mann-Whitney & $p=0.007^{*}, Z=-2.697, r=0.264$ \\
VL & Q1-pre vs. Q1-post & Wilcoxon signed ranks & $p<0.001^{*}, Z=-6.053, r=0.856$ \\
C & Q1-pre vs. Q1-post & Wilcoxon signed ranks & $p<0.001^{*}, Z=-6.201, r=0.860$ \\
\hline
\end{tabular}

*Significant difference visualizations, which were lower than those attained by the other two groups.

Therefore, it can be concluded that learning was equally promoted by these different experimental practices. Declarative knowledge acquisition requires the activation of the learner's cognitive resources for the recollection of facts and events, which allows for comparing and contrasting remembered material (Kump et al., 2015). Understanding and memorizing the learning content is crucial in learning declarative knowledge, while exercising an operating process is very important in learning procedural knowledge (Hong et al., 2018). The presentation (Hong et al., 2018) of meaningful activities (Glasson, 1989) may foster declarative knowledge acquisition.

Activities incorporating virtual or physical or blended representations promote learning through different mechanisms that are either additive or interfere one another (Rau, 2020). Given that in this study only RLs or VLs through demonstration were implemented, students did not interact with physical or virtual representations. Consequently, there were no haptic cues since hands-on activities through touch sensory channel were absent nor a possible raise in interest through physical engagement appeared (Zacharia et al., 2019). Learning in activities by demonstration can only be attributed in mechanisms promoted by different conceptual salient characteristics of real and virtual representations (Rau, 2020; Olympiou \& Zacharia, 2012), in cognitive load management of virtual representations (van Merriënboer \& Sweller, 2005; Zacharia \& Olympiou, 2011; Vogel-Walcutt et al., 2011; Korakakis et al., 2009; Mayer \& Moreno, 2002) and embodied schema evolvement through neural mirroring mechanisms (Rau, 2020; Duijzer et al., 2019; Gallese, 2009; Ebisch et al., 2008). Nevertheless, further research is necessary in order to determine how these learning mechanisms are promoted by experiments through demonstration.

Several classrooms in Greece have been equipped with IBs, and many secondary education teachers have been trained for its use. At the same time, a great variety of digital educational objects including VLs are available in various repositories, to be used as a substitute or alongside hands on experiments with physical instruments. VLs provide opportunities when physical laboratories are not available or practical (Davenport 2018). Arduino experiments may bridge the gap of virtual vs. physical instrumentation as being a tool to conduct experiments with physical instruments and substances in a mixed virtual-physical learning environment.

\section{Implications}

In everyday praxis, we often need demonstration measuring devices (thermometers, $\mathrm{pH}$ meters, etc.), with large enough displays to be easily readable from every point in the classroom (Kubínová \& Šlégr, 2015). The findings of this study imply that virtual experimentation and Arduino experiments through a demonstration using IBs, in a mixed virtual-physical environment provide learning gains greater than those achieved by using static visualizations. As implementing Arduino experiments or VLs result in significant learning gains, they could be proposed for enhancing students' declarative knowledge in the context of acids and bases in secondary education. Nevertheless, learning through hands-on activities experiments is also promoted by mechanisms explained by physical engagement and haptic cues, which are not present in demonstrations.

Given the differing affordances of physical and virtual manipulatives, combining their use is the only way to reap and use the benefits (advantageous affordances) that 
both carry (Olympiou \& Zacharia, 2012) in order to offer advantages that neither one can fully achieve by itself (De Jong et al., 2013). Therefore, designers of digital educational environments should provide educators and students the means to implement appropriate sequences of VLs and RLs in a mixed virtual-physical environment and Arduino looks appropriate to facilitate this procedure either with a demonstration as in this study or in hands-on form.

However, as there is no consensus or generally accepted rules regarding best practices in the sequence of virtual lab and physical lab components (Brinson, 2015; Zacharia et al., 2019), it is important to provide to the educators and students opportunities to draw and follow their own learning path based on the unique affordances of each mode of experimentation (Olympiou \& Zacharia, 2012). Activities incorporated in teaching practices should be chosen appropriately, taking into account the subject to be taught as well as the available infrastructure involving a variety of combinations of virtual and physical experiments (Brinson, 2017). A mixed virtual-physical learning environment has to facilitate the alternative learning paths, and it is appropriate for educational systems, where various barriers (e.g. limited infrastructure) confront with hands-on experimentation in real lab (Davenport, 2018; Tatli \& Ayas, 2013; Tountoulidis, 2011). Arduino instrumentation is appropriate for this purpose since it can transmit data from sensors to a PC by using inexpensive infrastructure (Grinias et al., 2016) and therefore bridge the gap between virtual learning environment and real instruments. In such an environment, a teacher may substitute activities that integrate virtual objects with activities that incorporate physical counterparts through the use of Arduino sensors and vice versa. It should be noted that virtual representations can also be used in cases where school lessons have to be substituted by online learning and hands-on activities by experiments through demonstration as happened in Greece due to the Covid-19 pandemic in 2020. A mixed virtual-physical environment may prove useful, but research is needed to evaluate the learning effects in these cases.

\section{Limitations and Future Research}

This study's results should be interpreted taking into account some limitations. First, only declarative knowledge acquisition and experiments through demonstration were considered in this study as these are the main characteristics in the context of common Greek secondary education practices. Learning mechanisms involved in Arduino experiments or VLs by demonstration are different than mechanisms involved in hands-on experiments. Therefore, this study can be considered only applicable to situations where only demonstrations and no other processes like hands-on experiments take place. A future research could be designed in such a way in order to clarify which were the characteristics of the physical or virtual representations that were beneficial or detrimental for learning.

In addition, using the same test as pre-test and posttest could have compromised internal validity. However, the time that elapsed between the pre-test and posttest questionnaire minimized the students' opportunity to memorize the questions. Finally, due to practical circumstances, a quasi-experimental setup was used. The school classes used in this study did not differ on scores on the pre-tests, but random assignment of students to the different experimental conditions would have minimized possible class-related effects.

\section{Appendix}

The following are the questions used in the questionnaires Q1 and Q2. We indicated each student to read carefully every question and to give his/her answer. Only one answer is correct.

\begin{tabular}{|c|c|c|c|c|c|}
\hline Questions & $\begin{array}{l}\text { Answer } \\
\text { a }\end{array}$ & $\begin{array}{l}\text { Answer } \\
\text { b }\end{array}$ & $\begin{array}{l}\text { Answer } \\
\text { c }\end{array}$ & $\begin{array}{l}\text { Answer } \\
\text { D }\end{array}$ & $\begin{array}{l}\text { Question- } \\
\text { naires }\end{array}$ \\
\hline $\begin{array}{l}\text { 1. Which } \\
\text { one of the } \\
\text { follow- } \\
\text { ing is an } \\
\text { acidic } \\
\text { solution? }\end{array}$ & Vinegar & $\begin{array}{c}\text { Baking } \\
\text { soda }\end{array}$ & $\begin{array}{l}\text { Glass } \\
\text { cleaner }\end{array}$ & $\begin{array}{l}\text { Drain } \\
\text { cleaner }\end{array}$ & $\begin{array}{c}\text { Q1 and } \\
\text { Q2 }\end{array}$ \\
\hline $\begin{array}{l}\text { 2. Which } \\
\text { one of the } \\
\text { following } \\
\text { gives an } \\
\text { alkaline } \\
\text { solution } \\
\text { when it is } \\
\text { dissolved } \\
\text { in water? }\end{array}$ & $\mathrm{CH}_{3} \mathrm{COOH}$ & $\mathrm{NaOH}$ & $\mathrm{H}_{2} \mathrm{SO}_{4}$ & $\mathrm{HNO}_{3}$ & $\begin{array}{c}\text { Q1 and } \\
\text { Q2 }\end{array}$ \\
\hline $\begin{array}{l}\text { 3. If we add } \\
\text { water to } \\
\text { an acidic } \\
\text { solution } \\
\text { the value } \\
\text { of } \mathrm{pH} \text { : }\end{array}$ & Increases & Decreases & $\begin{array}{c}\text { Remains } \\
\text { con- } \\
\text { stant }\end{array}$ & $\begin{array}{l}\text { We } \\
\text { cannot } \\
\text { predict }\end{array}$ & $\begin{array}{l}\text { Q1 and } \\
\text { Q2 }\end{array}$ \\
\hline $\begin{array}{l}\text { 4. Distilled } \\
\text { water }\end{array}$ & $\begin{array}{c}\text { Does not } \\
\text { contain } \\
\text { any ions }\end{array}$ & $\begin{array}{l}\text { Contains } \\
\text { only } \mathrm{H}^{+}\end{array}$ & $\begin{array}{c}\text { Contains } \\
\text { only } \\
\mathrm{OH}^{-}\end{array}$ & $\begin{array}{l}\begin{array}{c}\text { Contains } \\
\text { both }\end{array} \\
\mathrm{H}^{+} \text {and } \\
\mathrm{OH}^{-}\end{array}$ & $\begin{array}{l}\text { Q1 and } \\
\text { Q2 }\end{array}$ \\
\hline $\begin{array}{l}\text { 5. An acidic } \\
\text { solution } \\
\text { at } 25^{\circ} \mathrm{C} \\
\text { has: }\end{array}$ & $\mathrm{pH}=7$ & $\mathrm{pH}<7$ & $\mathrm{pH}>7$ & $\mathrm{pH}=14$ & $\begin{array}{l}\text { Q1 and } \\
\text { Q2 }\end{array}$ \\
\hline
\end{tabular}




\begin{tabular}{|c|c|c|c|c|c|c|c|c|c|c|c|}
\hline Questions & $\begin{array}{l}\text { Answer } \\
\text { a }\end{array}$ & $\begin{array}{l}\text { Answer } \\
\text { b }\end{array}$ & $\begin{array}{l}\text { Answer } \\
\text { c }\end{array}$ & $\begin{array}{l}\text { Answer } \\
\text { D }\end{array}$ & $\begin{array}{l}\text { Question- } \\
\text { naires }\end{array}$ & Questions & $\begin{array}{l}\text { Answer } \\
\text { a }\end{array}$ & $\begin{array}{l}\text { Answer } \\
\text { b }\end{array}$ & $\begin{array}{l}\text { Answer } \\
\text { c }\end{array}$ & $\begin{array}{l}\text { Answer } \\
\text { D }\end{array}$ & $\begin{array}{l}\text { Question- } \\
\text { naires }\end{array}$ \\
\hline $\begin{array}{l}\text { 6. Acids are } \\
\text { sub- } \\
\text { stances } \\
\text { that when } \\
\text { they are }\end{array}$ & \multirow[t]{2}{*}{$\mathrm{H}_{2}$} & \multirow[t]{2}{*}{$\mathrm{CO}_{2}$} & \multirow[t]{2}{*}{$\mathrm{O}_{2}$} & \multirow[t]{2}{*}{$\overline{\mathrm{H}^{+}}$} & \multirow[t]{2}{*}{$\begin{array}{c}\text { Q1 and } \\
\text { Q2 }\end{array}$} & $\begin{array}{l}\text { 12. An } \\
\text { alkaline } \\
\text { solution } \\
\text { at } 25^{\circ} \mathrm{C} \\
\text { has: }\end{array}$ & $\mathrm{pH}=7$ & $\mathrm{pH}<7$ & $\mathrm{pH}>7$ & $\mathrm{pH}=0$ & $\begin{array}{l}\text { Q1 and } \\
\text { Q2 }\end{array}$ \\
\hline $\begin{array}{l}\text { dissolved } \\
\text { in water } \\
\text { produce: }\end{array}$ & & & & & & \multirow{3}{*}{$\begin{array}{l}\text { 13. pH is } \\
\text { measured } \\
\text { at higher } \\
\text { precision } \\
\text { with the } \\
\text { use of: } \\
\text { 14. If we } \\
\text { add water } \\
\text { to an } \\
\text { alkaline } \\
\text { solution } \\
\text { then the } \\
\text { pH value: }\end{array}$} & \multirow[t]{2}{*}{$\begin{array}{l}\text { An indica- } \\
\text { tor }\end{array}$} & \multirow[t]{2}{*}{$\begin{array}{l}\text { A pH } \\
\text { meter } \\
\text { paper }\end{array}$} & \multirow[t]{2}{*}{$\begin{array}{l}\text { A digital } \\
\mathrm{pH} \\
\text { meter }\end{array}$} & \multirow[t]{2}{*}{$\begin{array}{l}\text { A bal- } \\
\text { ance }\end{array}$} & \multirow[t]{2}{*}{$\begin{array}{l}\text { Q1 and } \\
\text { Q2 }\end{array}$} \\
\hline $\begin{array}{l}\text { 7. Our } \\
\text { stomach } \\
\text { contains }\end{array}$ & \multirow[t]{3}{*}{$\begin{array}{l}\text { Lemon } \\
\text { juice }\end{array}$} & \multirow[t]{3}{*}{$\begin{array}{l}\text { Orange } \\
\text { juice }\end{array}$} & \multirow{3}{*}{$\begin{array}{l}\text { Baking } \\
\text { soda } \\
\text { solu- } \\
\text { tion }\end{array}$} & \multirow[t]{3}{*}{ Vinegar } & \multirow[t]{3}{*}{ Q1 } & & & & & & \\
\hline $\begin{array}{l}\text { an acidic } \\
\text { solution. } \\
\text { If the } \\
\text { concentra- } \\
\text { tion of the } \\
\text { solution } \\
\text { increases, }\end{array}$ & & & & & & & Increases & Decreases & $\begin{array}{l}\text { Remains } \\
\text { stable }\end{array}$ & $\begin{array}{l}\text { We } \\
\text { cannot } \\
\text { predict }\end{array}$ & Q1 \\
\hline $\begin{array}{l}\text { then we } \\
\text { feel a } \\
\text { stomach } \\
\text { burn. In } \\
\text { order to } \\
\text { decrease } \\
\text { the con- } \\
\text { centration } \\
\text { of the acid } \\
\text { in our } \\
\text { stomach } \\
\text { solution } \\
\text { we should } \\
\text { drink: }\end{array}$ & & & & & & \multirow{4}{*}{$\begin{array}{l}\text { 15. Bro- } \\
\text { mothymol } \\
\text { Blue is an } \\
\text { indicator } \\
\text { that gets: } \\
\text { yellow } \\
\text { color at } \\
\text { pH }<6, \\
\text { green } \\
\text { color } \\
\text { at pH } \\
\text { between } \\
6.5 \text { and } \\
7.5 \text { blue } \\
\text { color at } \\
\text { pH greater } \\
\text { than } 7.5 . \\
\text { We add a } \\
\text { few drops } \\
\text { of the } \\
\text { indica- } \\
\text { tor into } \\
\text { a beaker } \\
\text { containing } \\
\text { a liquid. If } \\
\text { the indica- } \\
\text { tor gets a } \\
\text { blue color, } \\
\text { which } \\
\text { of the } \\
\text { following } \\
\text { may be } \\
\text { the liquid? }\end{array}$} & Water & Vinegar & $\begin{array}{l}\text { Ammo- } \\
\text { nia } \\
\text { solution }\end{array}$ & $\begin{array}{c}\text { Lemon } \\
\text { juice }\end{array}$ & Q2 \\
\hline $\begin{array}{l}\text { 9. A neutral } \\
\text { solution: }\end{array}$ & $\begin{array}{l}\text { Contains no } \\
\text { ions }\end{array}$ & $\begin{array}{l}\text { Contains } \\
\text { only } \\
\text { water }\end{array}$ & $\begin{array}{c}\text { Contains } \\
\text { neither } \\
\mathrm{H}^{+} \text {nor } \\
\mathrm{OH}^{-}\end{array}$ & $\begin{array}{l}\text { Contains } \\
\text { an } \\
\text { equal } \\
\text { number } \\
\text { of } \mathrm{H}^{+} \\
\text {and } \\
\mathrm{OH}^{-}\end{array}$ & $\begin{array}{l}\text { Q1 and } \\
\text { Q2 }\end{array}$ & & & & & & \\
\hline \multirow{2}{*}{$\begin{array}{l}\text { 10. When } \\
\text { an acidic } \\
\text { solution } \\
\text { is mixed } \\
\text { with an } \\
\text { alkaline } \\
\text { solution } \\
\text { then the } \\
\text { resulting } \\
\text { solution: }\end{array}$} & \multirow[t]{2}{*}{$\begin{array}{c}\text { Is always } \\
\text { neutral }\end{array}$} & \multirow[t]{2}{*}{$\begin{array}{l}\text { Is always } \\
\text { acidic }\end{array}$} & \multirow[t]{2}{*}{$\begin{array}{l}\text { Is always } \\
\text { alkaline }\end{array}$} & \multirow{2}{*}{$\begin{array}{l}\text { It can be } \\
\text { either } \\
\text { acidic } \\
\text { either } \\
\text { neutral } \\
\text { either } \\
\text { alkaline }\end{array}$} & \multirow[t]{2}{*}{ Q1 } & & & & & & \\
\hline & & & & & & & & & & & \\
\hline $\begin{array}{l}\text { 11. Hydro- } \\
\text { chloric } \\
\text { acid solu- } \\
\text { tion reacts } \\
\text { with: }\end{array}$ & $\begin{array}{l}\text { Certain } \\
\text { metals }\end{array}$ & All metals & $\begin{array}{c}\text { Neutral } \\
\text { solu- } \\
\text { tions }\end{array}$ & $\begin{array}{r}\text { Acidic } \\
\text { solu- } \\
\text { tions }\end{array}$ & $\begin{array}{l}\text { Q1 and } \\
\text { Q2 }\end{array}$ & & & & & & \\
\hline
\end{tabular}




\begin{tabular}{|c|c|c|c|c|c|c|c|c|c|c|c|}
\hline Questions & $\begin{array}{l}\text { Answer } \\
\mathrm{a}\end{array}$ & $\begin{array}{l}\text { Answer } \\
\mathrm{b}\end{array}$ & $\begin{array}{l}\text { Answer } \\
\mathrm{c}\end{array}$ & $\begin{array}{l}\text { Answer } \\
\text { D }\end{array}$ & $\begin{array}{l}\text { Question- } \\
\text { naires }\end{array}$ & Questions & $\begin{array}{l}\text { Answer } \\
\text { a }\end{array}$ & $\begin{array}{l}\text { Answer } \\
\text { b }\end{array}$ & $\begin{array}{l}\text { Answer } \\
\mathrm{c}\end{array}$ & $\begin{array}{l}\text { Answer } \\
\text { D }\end{array}$ & $\begin{array}{l}\text { Question- } \\
\text { naires }\end{array}$ \\
\hline $\begin{array}{l}\text { 16. Which } \\
\text { of the } \\
\text { following } \\
\text { sub- } \\
\text { stances } \\
\text { gives an } \\
\text { acidic } \\
\text { solution } \\
\text { when dis- } \\
\text { solved in } \\
\text { water? }\end{array}$ & $\mathrm{HCl}$ & $\mathrm{NH}_{3}$ & $\mathrm{NaOH}$ & $\mathrm{Ca}(\mathrm{OH})_{2}$ & $\begin{array}{c}\text { Q1 and } \\
\text { Q2 }\end{array}$ & $\begin{array}{l}\text { 21. A solu- } \\
\text { tion has } \\
\mathrm{pH}=8 . \\
\text { If the } \\
\text { solution } \\
\text { is divided } \\
\text { into two } \\
\text { equal } \\
\text { parts, the } \\
\text { pH value } \\
\text { of each }\end{array}$ & 4 & 8 & 12 & $\begin{array}{l}\text { We } \\
\text { cannot } \\
\text { predict }\end{array}$ & Q1 \\
\hline $\begin{array}{l}\text { 17. A } \\
\text { beaker }\end{array}$ & Increases & Decreases & $\begin{array}{c}\text { Remains } \\
\text { stable }\end{array}$ & $\begin{array}{l}\text { We } \\
\text { cannot }\end{array}$ & Q1 & $\begin{array}{l}\text { part will } \\
\text { be: }\end{array}$ & & & & & \\
\hline $\begin{array}{l}\text { contains } \\
10 \text { mL of } \\
\text { an acidic } \\
\text { solution. } \\
\text { If we } \\
\text { add an }\end{array}$ & & & & predict & & $\begin{array}{l}\text { 22. Neu- } \\
\text { tralization } \\
\text { occurs } \\
\text { when: }\end{array}$ & $\begin{array}{l}\text { We mix } \\
\text { an acidic } \\
\text { with an } \\
\text { alkaline } \\
\text { solution }\end{array}$ & $\begin{array}{l}\text { We mix } \\
\text { two } \\
\text { neutral } \\
\text { solutions }\end{array}$ & $\begin{array}{l}\text { We add } \\
\text { water } \\
\text { to an } \\
\text { acidic } \\
\text { solu- } \\
\text { tion }\end{array}$ & $\begin{array}{l}\text { We add } \\
\text { water } \\
\text { to an } \\
\text { alkaline } \\
\text { solution }\end{array}$ & Q1 \\
\hline $\begin{array}{l}\text { additional } \\
\text { amount of } \\
\text { the same } \\
\text { solution to } \\
\text { the beaker } \\
\text { then the } \\
\text { pH: }\end{array}$ & & & & & & $\begin{array}{l}\text { 23. An indi- } \\
\text { cator gets: } \\
\text { red color } \\
\text { at } \mathrm{pH}<3 \text {, } \\
\text { orange } \\
\text { color } \\
\text { at } \mathrm{pH}\end{array}$ & Vinegar & Water & $\begin{array}{l}\text { Drain } \\
\text { cleaner } \\
\text { solu- } \\
\text { tion }\end{array}$ & $\begin{array}{l}\text { Baking } \\
\text { soda } \\
\text { solution }\end{array}$ & $\begin{array}{c}\text { Q1 and } \\
\text { Q2 }\end{array}$ \\
\hline $\begin{array}{l}\text { 18. When } \\
\text { mixing } \\
\mathrm{NaOH} \\
\text { with } \mathrm{HCl} \\
\text { solution: }\end{array}$ & $\begin{array}{c}\mathrm{Na}^{+} \text {reacts } \\
\text { with } \mathrm{H}^{+}\end{array}$ & $\begin{array}{l}\mathrm{Cl}^{-} \text {reacts } \\
\text { with } \\
\mathrm{OH}^{-}\end{array}$ & $\begin{array}{c}\mathrm{H}^{+} \text {reacts } \\
\text { with } \\
\mathrm{OH}^{-}\end{array}$ & $\begin{array}{l}\text { No reac- } \\
\text { tion } \\
\text { occurs }\end{array}$ & Q1 & $\begin{array}{l}\text { between } \\
3 \text { and } 3.5 \text {, } \\
\text { yellow } \\
\text { color at } \\
\mathrm{pH}>3.5 \text {. }\end{array}$ & & & & & \\
\hline \multirow{3}{*}{$\begin{array}{l}\text { 20. In a } \\
\text { solution } \\
\text { with } \\
\mathrm{pH}=10 \\
\text { we add a } \\
\text { solution } \\
\text { of } \mathrm{pH}=2 \text {. } \\
\text { The } \mathrm{pH} \\
\text { value of } \\
\text { the result- } \\
\text { ing solu- } \\
\text { tion is: }\end{array}$} & 2 & $\begin{array}{l}\text { In the } \\
\text { range } \\
\text { between } \\
2 \text { and } 10\end{array}$ & 10 & 12 & Q1 & $\begin{array}{l}\text { a liquid. If } \\
\text { the indica- } \\
\text { tor gets a } \\
\text { red color, } \\
\text { which } \\
\text { of the } \\
\text { following } \\
\text { may be } \\
\text { the liquid? }\end{array}$ & & & & & \\
\hline & & & & & & \multirow{2}{*}{$\begin{array}{l}\text { 24. A wasp } \\
\text { has a } \\
\text { poison } \\
\text { that is an } \\
\text { alkaline } \\
\text { solution. } \\
\text { Which } \\
\text { of the } \\
\text { following } \\
\text { can you } \\
\text { use for the } \\
\text { treatment } \\
\text { of a wasp } \\
\text { tweak? }\end{array}$} & \multirow[t]{2}{*}{$\begin{array}{c}\text { Ammonia } \\
\text { solution }\end{array}$} & \multirow[t]{2}{*}{$\begin{array}{l}\text { Baking } \\
\text { soda } \\
\text { solution }\end{array}$} & \multirow[t]{2}{*}{ Vinegar } & \multirow[t]{2}{*}{$\begin{array}{l}\text { Soap } \\
\text { water }\end{array}$} & \multirow[t]{2}{*}{ Q1 } \\
\hline & & & & & & & & & & & \\
\hline
\end{tabular}




\begin{tabular}{|c|c|c|c|c|c|}
\hline Questions & $\begin{array}{l}\text { Answer } \\
\text { a }\end{array}$ & $\begin{array}{l}\text { Answer } \\
\text { b }\end{array}$ & $\begin{array}{l}\text { Answer } \\
\text { c }\end{array}$ & $\begin{array}{l}\text { Answer } \\
\text { D }\end{array}$ & $\begin{array}{l}\text { Question- } \\
\text { naires }\end{array}$ \\
\hline $\begin{array}{l}25 . \text { If } \\
\text { marble } \\
\text { powder is } \\
\text { added in } \\
\text { a solution } \\
\text { of hydro- } \\
\text { chloric } \\
\text { acid: }\end{array}$ & $\begin{array}{l}\text { No reaction } \\
\text { is carried } \\
\text { out }\end{array}$ & $\begin{array}{l}\text { A reaction } \\
\text { is car- } \\
\text { ried out } \\
\text { and } \mathrm{H}_{2} \\
\text { is pro- } \\
\text { duced }\end{array}$ & $\begin{array}{l}\text { A reac- } \\
\text { tion is } \\
\text { carried } \\
\text { out and } \\
\mathrm{CO}_{2} \text { is } \\
\text { pro- } \\
\text { duced }\end{array}$ & $\begin{array}{l}\text { A reac- } \\
\text { tion is } \\
\text { carried } \\
\text { out and } \\
\mathrm{O}_{2} \text { is } \\
\text { pro- } \\
\text { duced }\end{array}$ & Q1 \\
\hline $\begin{array}{l}\text { 26. If iron } \\
\text { powder is } \\
\text { added in } \\
\text { a solution } \\
\text { of hydro- } \\
\text { chloric } \\
\text { acid: }\end{array}$ & $\begin{array}{l}\text { No reaction } \\
\text { is carried } \\
\text { out }\end{array}$ & $\begin{array}{l}\text { A reaction } \\
\text { is car- } \\
\text { ried out } \\
\text { and } \mathrm{H}_{2} \\
\text { is pro- } \\
\text { duced }\end{array}$ & $\begin{array}{l}\text { A reac- } \\
\text { tion is } \\
\text { carried } \\
\text { out and } \\
\mathrm{CO}_{2} \text { is } \\
\text { pro- } \\
\text { duced }\end{array}$ & $\begin{array}{l}\text { A reac- } \\
\text { tion is } \\
\text { carried } \\
\text { out and } \\
\mathrm{O}_{2} \text { is } \\
\text { pro- } \\
\text { duced }\end{array}$ & Q1 \\
\hline
\end{tabular}

Broman, K., Bernholt, S., \& Parchmann, I. (2018). Using model-based scaffolds to support students solving context-based chemistry problems. International journal of science education. https://doi. org/10.1080/09500693.2018.1470350.

Bulte, A. M. W., Westbroek, H. B., de Jong, O., \& Pilot, A. (2006). A research approach to designing chemistry education using authentic practices as contexts. International journal of science education. https://doi.org/10.1080/09500690600702520.

Camuffo, D. (1992). Acid rain and deterioration of monuments: how old is the phenomenon?, Atmospheric Environment. Part B. Urban Atmosphere. https://doi.org/10.1016/0957-1272(92)90027-P.

Cartrette, D. P., \& Mayo, P. M. (2011). Students' understanding of acids/bases in organic chemistry contexts. Chemistry education research and practice. https://doi.org/10.1039/C1RP90005F.

Charola, A. E. (1987). Acid rain effects on stone monuments. Journal of Chemical Education. https://doi.org/10.1021/ed064p436.

Chéron, M., Ademi, M., Kraft, F., \& Löffler-Stastka, H. (2016). Casebased learning and multiple choice questioning methods favored by students. BMC Medical Education. https://doi.org/10.1186/ s12909-016-0564-x.

Childs, P. E., Hayes, S. M., \& O'dwyer, A. (2015). Chemistry and everyday life: relating secondary school chemistry to the current and future lives of students. In I. Eilks \& A. Hofstein (Eds.). Relevant Chemistry Education: From Theory to Practice (pp. 33-54). Rotterdam: SensePublishers, https://doi. org/10.1007/978-94-6300-175-5_3.

Conflict of Interest The authors declare that they have no conflict of interest.

Ethical Approval All procedures performed in studies involving human participants were in accordance with the ethical standards of the institutional and national research committee and with the 1964 Helsinki declaration and its later amendments or comparable ethical standards.

Informed Consent Informed consent was obtained from all individual participants included in the study.

\section{References}

Abu-Zaid, A., \& Khan, T. A. (2013). Assessing declarative and procedural knowledge using multiple-choice questions. Medical Education Online. https://doi.org/10.3402/meo.v18i0.21132.

Ackerman, T. A., \& Smith, P. L. (1988). A comparison of the information provided by essay, multiple-choice, and free-response writing tests. Applied Psychological Measurement. https://doi. org/10.1177/014662168801200202.

Alò, D., Castillo, A., Marín Vial, P., \& Samaniego, H. (2020). Low-cost emerging technologies as a tool to support informal environmental education in children from vulnerable public schools of southern Chile. International journal of science education. https://doi.org/10.1080/09500693.2020.1723036.

Anderson, J. R. (1983). The architecture of cognition. Cambridge, MA: Harvard University Press.

Baedecker, P. A., \& Reddy, M. M. (1993). The erosion of carbonate stone by acid rain: laboratory and field investigations. Journal of Chemical Education. https://doi.org/10.1021/ed070p104.

Brinson, J. R. (2015). Learning outcome achievement in nontraditional (virtual and remote) versus traditional (hands-on) laboratories: a review of the empirical research. Computers \& Education. https://doi.org/10.1016/j.compedu.2015.07.003.

Brinson, J. R. (2017). A further characterization of empirical research related to learning outcome achievement in remote and virtual science labs. Journal of Science Education and Technology. https://doi.org/10.1007/s10956-017-9699-8.

Conrads, J., Rasmussen, M., Winters, N., Geniet, A., \& Langer, L. (2017). Digital education policies in Europe and beyond: key design principles for more effective policies. https://publications.jrc. ec.europa.eu/repository/handle/JRC109311 Accessed 31 March 2020.

Considine, J., Botti, M., \& Thomas, S. (2005). Design, format, validity and reliability of multiple choice questions for use in nursing research and education. Collegian. https://doi.org/10.1016/S1322-7696(08)60478-3.

Costa, S. C., \& Fernandes, J. C. B. (2019). Listening to pH. Journal of Chemical Education, 96(2), 372-376. https://doi.org/10.1021/ acs.jchemed.8b00641.

Crandall, P. G., O'Bryan, C. A., Killian, S. A., Beck, D. E., Jarvis, N., \& Clausen, E. (2015). A comparison of the degree of student satisfaction using a simulation or a traditional wet lab to teach physical properties of ice. Journal of Food Science Education. https://doi.org/10.1111/1541-4329.12049.

Clark, R. E. (1994). Media will never influence learning. Educational Technology Research and Development. https://doi.org/10.1007/ BF02299088.

Comi, S. L., Argentin, G., Gui, M., Origo, F., \& Pagani, L. (2017). Is it the way they use it? Teachers, ICT and student achievement: Economics of Education Review. https://doi.org/10.1016/j. econedurev.2016.11.007.

Cristia, J., Ibarrarán, P., Cueto, S., Santiago, A., \& Severín, E. (2017). Technology and child development: evidence from the one laptop per child program. American Economic Journal: Applied Economics. https://doi.org/10.1257/app.20150385.

Dalgarno, B., Bishop, A. G., Adlong, W., \& Bedgood, D. R. (2009). Effectiveness of a Virtual Laboratory as a preparatory resource for Distance Education chemistry students. Computers \& Education. https://doi.org/10.1016/j.compedu.2009.05.005.

Davenport, J. L., Rafferty, A. N., \& Yaron, D. J. (2018). Whether and how authentic contexts using a virtual chemistry lab support learning. Journal of Chemical Education, 95(8), 1250-1259. https://doi.org/10.1021/acs.jchemed.8b00048.

Ding, L., \& Beichner, R. (2009). Approaches to data analysis of multiplechoice questions. Physical Review Special Topics - Physics Education Research. https://doi.org/10.1103/PhysRevSTPER. 5.020103 . 
De Jong, T. (2019). Moving towards engaged learning in STEM domains; there is no simple answer, but clearly a road ahead. Journal of Computer Assisted Learning. https://doi.org/10.1111/jcal.12337.

De Jong, T., Linn, M., \& Zacharia, Z. (2013). Physical and Virtual Laboratories in Science and Engineering Education. Science (New York, N.Y.), 340, 305-308. https://doi.org/10.1126/science. 1230579

Demircioglu, G., Ayas, A., \& Demircioglu, H. (2005). Conceptual change achieved through a new teaching program on acids and bases. Chemistry Education Research Practice. https://doi.org/10.1039/ B4RP90003K.

DFRobot (2019). pH meter. https://wiki.dfrobot.com/PH_meter_ SKU_SEN0161_. Accessed 27 March 2020.

Dickson-Spillmann, M., Siegrist, M., \& Keller, C. (2011). Development and validation of a short, consumer-oriented nutrition knowledge questionnaire. Appetite. https://doi.org/10.1016/j.appet. 2011.01.034.

Duijzer, C., Van den Heuvel-Panhuizen, M., Veldhuis, M., Doorman, M., \& Leseman, P. (2019). Embodied learning environments for graphing motion: a systematic literature review. Educational Psychology Review. https://doi.org/10.1007/s10648-019-09471-7.

Ebisch, S. J. H., Perrucci, M. G., Ferretti, A., Del Gratta, C., Romani, G. L., \& Gallese, V. (2008). The sense of touch: embodied simulation in a visuotactile mirroring mechanism for observed animate or inanimate touch. Journal of Cognitive Neuroscience. https://doi.org/10.1162/ jocn.2008.20111.

Edwards, B. I., Bielawski, K. S., Prada, R., \& Cheok, A. D. (2019). Haptic virtual reality and immersive learning for enhanced organic chemistry instruction. Virtual Reality. https://doi.org/10.1007/ s10055-018-0345-4.

Efstathiou, C., Hovardas, T., Xenofontos, N. A., Zacharia, Z. C., de Jong, T., Anjewierden, A., et al. (2018). Providing guidance in virtual lab experimentation: the case of an experiment design tool. Educational Technology Research and Development. https:// doi.org/10.1007/s11423-018-9576-z.

El Hammoumi, A., Motahhir, S., Chalh, A., El Ghzizal, A., \& Derouich, A. (2018). Low-cost virtual instrumentation of PV panel characteristics using Excel and Arduino in comparison with traditional instrumentation. Renewables: Wind, Water, and Solar. https://doi.org/10.1186/s40807-018-0049-0.

Enciso, P., Luzuriaga, L., \& Botasini, S. (2018). Using an opensource microcontroller and a dye-sensitized solar cell to guide students from basic principles to a practical application. Journal of Chemical Education. https://doi.org/10.1021/acs.jchemed. $8 \mathrm{~b} 00094$.

Escudero, E. B., Reyna, N. L., \& Morales, M. R. (2000). The level of difficulty and discrimination power of the Basic Knowledge and Skills Examination (EXHCOBA). Revista electrónica de investigación educativa, 2(1), 1-16.

European Commission. (2018). Communication from the Commission to the European Parliament, the Council, the European Economic and Social Committee and the Committee of the Regions. https:// eur-lex.europa.eu/legal-content/EN/TXT/PDF/?uri=CELEX: 52018DC0022\&from=EN. Accessed 31 March 2020.

Falck, O., Mang, C., \& Woessmann, L. (2018). Virtually no effect? Different Uses of Classroom Computers and their Effect on Student Achievement: Oxford Bulletin of Economics and Statistics. https:// doi.org/10.1111/obes.12192.

Fatani, A., Kanawi, A., Alshami, H., Bensenouci, A., Brahimi, T., \& Bensenouci, M. Dual pH level monitoring and control using IoT application. In 2018 15th Learning and Technology Conference (L\&T), 25-26 Feb. 2018. https://doi.org/10.1109/LT.2018.8368502.

Flick, L. B. (1993). The meanings of hands-on science. Journal of Science Teacher Education. https://doi.org/10.1007/BF02628851.

Fritz, C., E Morris, P., \& J Richler, J. (2011). Effect size estimates: current use, calculations, and interpretation. Journal of experimental psychology: General, https://doi.org/10.1037/ a0024338.

Gallese, V. (2009). Mirror neurons, embodied simulation, and the neural basis of social identification. Psychoanalytic Dialogues. https://doi. org/10.1080/10481880903231910.

Gianni, A., Zamparas, M., Papadas, I. T., Kehayias, G., Deligiannakis, Y., \& Zacharias, I. (2013). Monitoring and modeling of metal concentration distributions in anoxic basins: Aitoliko Lagoon. Greece, Aquatic Geochemistry,. https://doi.org/10.1007/s10498012-9179-y.

Glasson, G. E. (1989). The effects of hands-on and teacher demonstration laboratory methods on science achievement in relation to reasoning ability and prior knowledge. Journal of Research in Science Teaching. https://doi.org/10.1002/tea.3660260204.

Goldstone, R. L., \& Son, J. Y. (2005). The transfer of scientific principles using concrete and idealized simulations. Journal of the Learning Sciences. https://doi.org/10.1207/s15327809jls1401_4.

Grzegorzewski, P., \& Śpiewak, M. (2019). The sign test and the signedrank test for interval-valued data. International Journal of Intelligent Systems. https://doi.org/10.1002/int.22134.

Grinias, J. P., Whitfield, J. T., Guetschow, E. D., \& Kennedy, R. T. (2016). An inexpensive, open-source USB Arduino data acquisition device for chemical instrumentation. Journal of Chemical Education, https://doi.org/10.1021/acs.jchemed.6b00262.

Herranen, J., Kousa, P., Fooladi, E., \& Aksela, M. (2019). Inquiry as a context-based practice-a case study of pre-service teachers' beliefs and implementation of inquiry in context-based science teaching. International journal of science education. https:// doi.org/10.1080/09500693.2019.1655679.

Hong, J., Pi, Z., \& Yang, J. (2018). Learning declarative and procedural knowledge via video lectures: cognitive load and learning effectiveness. Innovations in Education and Teaching International. https://doi.org/10.1080/14703297.2016.1237371.

Horton, C. (2007). Student alternative conceptions in chemistry. California Journal of Science Education, 7(2), 18-28.

Itzek-Greulich, H., Flunger, B., Vollmer, C., Nagengast, B., Rehm, M., \& Trautwein, U. (2015). Effects of a science center outreach lab on school students' achievement-are student lab visits needed when they teach what students can learn at school? Learning and Instruction. https://doi.org/10.1016/j.learninstruc.2015.03.003.

Itzek-Greulich, H., Flunger, B., Vollmer, C., Nagengast, B., Rehm, M., \& Trautwein, U. (2017). Effectiveness of lab-work learning environments in and out of school: a cluster randomized study. Contemporary Educational Psychology. https://doi. org/10.1016/j.cedpsych.2016.09.005.

Kapici, H. O., Akcay, H., \& de Jong, T. (2019). Using hands-on and virtual laboratories alone or together-which works better for acquiring knowledge and skills? Journal of Science Education and Technology. https://doi.org/10.1007/s10956-018-9762-0.

Korakakis, G., Pavlatou, E. A., Palyvos, J. A., \& Spyrellis, N. (2009). 3D visualization types in multimedia applications for science learning: a case study for 8 th-grade students in Greece. Computers \& Education. https://doi.org/10.1016/j. compedu.2008.09.011.

Kuan, W. H., Tseng, C. H., Chen, S., \& Wong, C. C. (2016). Development of a computer-assisted instrumentation curriculum for physics students: using LabVIEW and Arduino platform. Journal of Science Education and Technology. https://doi.org/ 10.1007/s10956-016-9603-y.

Kubínová, S. t. p. n., \& Šlégr, J. (2015). ChemDuino: adapting Arduino for low-cost chemical measurements in lecture and laboratory. Journal of Chemical Education. https://doi. org/10.1021/ed5008102.

Kurbanoglu, N. I., \& Akim, A. (2010). The relationships between university students' chemistry laboratory anxiety, attitudes, and 
self-efficacy beliefs. Australian Journal of Teacher Education, https://doi.org/10.14221/ajte.2010v35n8.4

Kump, B., Moskaliuk, J., Cress, U., \& Kimmerle, J. (2015). Cognitive foundations of organizational learning: re-introducing the distinction between declarative and non-declarative knowledge. Frontiers in Psychology. https://doi.org/10.3389/fpsyg. 2015.01489.

Kumar, S. (2017). Acid rain-the major cause of pollution: its causes. Effects, International Journal of Applied Chemistry, 13(1), 53-58.

Ma, Y., Fairlie, R. W., Loyalka, P. K., \& Rozelle, S. (2020). Isolating the "Tech" from Edtech: experimental evidence on computer assisted learning in China. CESifo Working Paper.

MacFarland, T. W., \& Yates, J. M. (2016). Kruskal-Wallis H-test for oneway analysis of variance (ANOVA) by Ranks. In T. W. MacFarland \& J. M. Yates (Eds.), Introduction to nonparametric statistics for the biological sciences using $R$ (pp. 177-211). Cham: Springer International Publishing. https://doi. org/10.1007/978-3-319-30634-6_6.

Mavridis, A., \& Tsiatsos, T. (2017). Game-based assessment: investigating the impact on test anxiety and exam performance. Journal of Computer Assisted Learning. https://doi.org/10.1111/ jcal.12170.

Mayer, R. E., \& Moreno, R. (2002). Aids to computer-based multimedia learning. Learning and Instruction. https://doi. org/10.1016/S0959-4752(01)00018-4.

Muijs, D. (2010). Doing quantitative research in education with SPSS (2ed.). London: Sage Publications LTD.

Nichols, D. (2017). Arduino-based data acquisition into Excel, LabVIEW, and MATLAB. The Physics Teacher, doi, 10(1119/1), 4978720.

Nikolopoulou, K., \& Gialamas, V. (2016). Barriers to ICT use in high schools: Greek teachers' perceptions. Journal of Computers in Education. https://doi.org/10.1007/s40692-015-0052-z.

Olympiou, G., \& Zacharia, Z. C. (2012). Blending physical and virtual manipulatives: an effort to improve students' conceptual understanding through science laboratory experimentation. Science Education. https://doi.org/10.1002/sce.20463.

Palmer, E. J., \& Devitt, P. G. (2007). Assessment of higher-order cognitive skills in undergraduate education: modified essay or multiple choice questions? Research paper: BMC Medical Education. https://doi.org/10.1186/1472-6920-7-49.

Papadopoulos, N. J., \& Jannakoudakis, A. (2016). A chemical instrumentation course on microcontrollers and op amps. Construction of a pH Meter. Journal of Chemical Education, https://doi.org/10.1021/acs.jchemed.5b00743.

Pedaste, M., Mäeots, M., Siiman, L. A., de Jong, T., van Riesen, S. A. N., Kamp, E. T., et al. (2015). Phases of inquiry-based learning: definitions and the inquiry cycle. Educational Research Review. https://doi.org/10.1016/j.edurev.2015.02.003.

Petô, M. (2020). Teaching atmospheric physics using Arduino-based tools. AIP Conference Proceedings, 2218(1), 060003. https://doi. org/10.1063/5.0002282.

Pino, H., Pastor, V., Grimalt-Álvaro, C., \& López, V. (2019). Measuring $\mathrm{CO}_{2}$ with an Arduino: creating a low-cost, pocket-sized device with flexible applications that yields benefits for students and schools. Journal of Chemical Education, https://doi.org/10.1021/acs.jchemed.8b00473.

Potkonjak, V., Gardner, M., Callaghan, V., Mattila, P., Guetl, C., Petrović, V. M., \& Jovanović, K. (2016). Virtual laboratories for education in science, technology, and engineering: a review. Computers \& Education. https://doi.org/10.1016/j.compedu. 2016.02.002.

Rau, M. A. (2020). Comparing multiple theories about learning with physical and virtual representations: conflicting or complementary effects? Educational Psychology Review. https:// doi.org/10.1007/s10648-020-09517-1.
Roni, S. M., Merga, M. K., \& Morris, J. E. (2020). Analysis: difference between groups. In Conducting quantitative research in education (pp. 65-110): Springer. https://doi.org/10. 1007/978-981-13-9132-3_6.

Sariscsany, M. J., \& Pettigrew, F. (1997). Effectiveness of interactive video instruction on teacher's classroom management declarative knowledge. Journal of Teaching in Physical Education. https://doi. org/10.1123/jtpe.16.2.229.

Scheckler, R. K. (2003). Virtual labs: a substitute for traditional labs? International Journal of Developmental Biology, 47(2-3), 231-236.

Soong, R., Agmata, K., Doyle, T., Jenne, A., Adamo, T., \& Simpson, A. (2018). Combining the maker movement with accessibility needs in an undergraduate laboratory: a cost-effective text-to-speech multipurpose, Universal Chemistry Sensor Hub (MUCSH) for Students with Disabilities. Journal of Chemical Education, https:// doi.org/10.1021/acs.jchemed.8b00638.

Spikol, D., Ruffaldi, E., Dabisias, G., \& Cukurova, M. (2018). Supervised machine learning in multimodal learning analytics for estimating success in project-based learning. Journal of Computer Assisted Learning. https://doi.org/10.1111/jcal.12263.

Stevenson, J. (1998). Performance of the cognitive holding power questionnaire in schools. Learning and Instruction. https://doi. org/10.1016/S0959-4752(97)00029-7.

Suwondo, N., \& Sulisworo, D. (2017). Hands-on learning activity using an apparatus for transient phenomena in RC circuit based on Arduino UNO R3-LINX-Labview. International Journal of Online Engineering. https://doi.org/10.3991/ijoe.v13i01.6317.

Tatli, Z, \& Ayas, A. (2013). Effect of a virtual chemistry laboratory on students' achievement. Journal of Educational Technology Society \& Natural Resources, 16(1), 159-170.

Teyssier, M. (2019). Uduino. https://marcteyssier.com/uduino/. Accessed 27 March 2019.

Tomczak, M., \& Tomczak, E. (2014). The need to report effect size estimates revisited. An overview of some recommended measures of effect size. Trends in Sport Sciences, 21(1), 19-25.

Tountoulidis, G. (2011). Annual science school-lab reports, L.C.N.S. http://ekfe-nikaias.att.sch.gr/portal/files_pdf/apologismos_2011. pdf Accessed 17 April 2019.

Tsaparlis, G., \& Gorezi, M. (2005). A modification of a conventional expository physical chemistry laboratory to accommodate an inquiry/project-based component: method and students' evaluation. Canadian Journal of Science, Mathematics and Technology Education,. https://doi.org/10.1080/ 14926150509556647.

Ural, E. (2016). The effect of guided-inquiry laboratory experiments on science education students' chemistry laboratory attitudes, anxiety and achievement. Journal of Education and Training Studies, https://doi.org/10.11114/jets.v4i4.1395.

Urban, P. L. (2014). Open-source electronics as a technological aid in chemical education. Journal of Chemical Education. https://doi. org/10.1021/ed4009073.

Urban, P. L. (2015). Universal electronics for miniature and automated chemical assays. Analyst. https://doi.org/10.1039/c4an02013h.

Vagelatos, A., \& Angelopoulos, P. (2017, 25-28 April 2017). Evaluation of "pupils' laptop" initiative in secondary education in Greece: analyzing the qualitative results of a survey on teachers. Paper presented at the 2017 IEEE Global Engineering Education Conference (EDUCON). https://doi.org/10.1109/EDUCON. 2017.7942906.

van Merriënboer, J. J. G., \& Sweller, J. (2005). Cognitive load theory and complex learning: recent developments and future directions. Educational Psychology Review. https://doi.org/10.1007/s10648005-3951-0.

Vogel-Walcutt, J. J., Gebrim, J. B., Bowers, C., Carper, T. M., \&Nicholson, D. (2011). Cognitive load theory vs. constructivist 
approaches:Which best leads to efficient, deep learning? Journal of Computer AssistedLearning, 27(2), 133-145. https://doi.org/10. 1111/j.1365-2729.2010.00381.x.

Wahyuni, T. S., \& Analita, R. N. (2017). Guided-inquiry laboratory experiments to improve students' analytical thinking skills. AIP Conference Proceedings, doi, 10(1063/1), 5016010.

Walkowiak, M., \& Nehring, A. (2016). Using ChemDuino, Excel, and PowerPoint as tools for real-time measurement representation in class. Journal of Chemical Education. https://doi.org/10.1021/acs. jchemed.5b00923.

Wang, T. L., \& Tseng, Y. K. (2018). The comparative effectiveness of physical, virtual, and virtual-physical manipulatives on third-grade students' science achievement and conceptual understanding of evaporation and condensation. International Journal of Science and Mathematics Education. https://doi.org/10.1007/s10763016-9774-2.

Webster, R. (2016). Declarative knowledge acquisition in immersive virtual learning environments. Interactive Learning Environments. https://doi.org/10.1080/10494820.2014.994533.

Wu, B. J., Wong, S. K., \& Li, T. W. (2019). Virtual titration laboratory experiment with differentiated instruction. Computer Animation and Virtual Worlds. https://doi.org/10.1002/cav.1882.

Zacharia, Z. (2007). Comparing and combining real and virtual experimentation: an effort to enhance students' conceptual understanding of electric circuits. Journal of Computer Assisted Learning. https://doi.org/10.1111/j.1365-2729.2006.00215.x.
Zacharia, Z., \& Anderson, R. (2003). The effects of an interactive computer-based simulation prior to performing a laboratory inquiry-based experiment on students' conceptual understanding of physics. American Journal of Physics, doi, 10(1119/1), 1566427.

Zacharia, Z., \& Olympiou, G. (2011). Physical versus virtual manipulative experimentation in physics learning. Learning and Instruction. https://doi.org/10.1016/j.learninstruc.2010.03.001.

Zacharia, Z. C., Olympiou, G., \& Papaevripidou, M. (2008). Effects of experimenting with physical and virtual manipulatives on students' conceptual understanding in heat and temperature. Journal of Research in Science Teaching. https://doi.org/10.1002/tea.20260.

Zacharia, Z., Papaevripidou, M., \& Pavlou, I. (2019). Could simulations replace physical manipulatives in early science education? Global Learn 2019, https://www.learntechlib.org/p/210308.

Zendler, A., \& Greiner, H. (2020). The effect of two instructional methods on learning outcome in chemistry education: the experiment method and computer simulation. Education for Chemical Engineers. https://doi.org/10.1016/j.ece.2019.09.001.

Publisher's Note Springer Nature remains neutral with regard to jurisdictional claims in published maps and institutional affiliations. 